\title{
POTENTIAL OF BIOMETHANE FROM WASHED ASHORE ALGAE IN GULF OF RIGA
}

\author{
Vilis Dubrovskis ${ }^{1}$, Valdis Bisters ${ }^{2}$, Juris Burlakovs ${ }^{3}$ \\ ${ }^{1}$ Latvia University of Life Sciences and Technologies, Latvia; ${ }^{2}$ University of Latvia, Latvia; ${ }^{3}$ Estonian \\ University of Life Sciences, Estonia \\ vilisd@inbox.lv
}

\begin{abstract}
There is a strong tourism industry with a high recreational value in the southern Baltic, which is adversely affected by the algae that accumulate along the coast. The project's concept of transforming the problem into a resource by preventing eutrophication through biogas production has several benefits for the region: removal of phosphorus and nitrogen from the Baltic Sea and their return to arable land (phosphorus is a limited resource to be saved for future food production); improved coastal recreation values and, in the long term, the regional economy; reduction of greenhouse gas (GHG) emissions from algae. Algae can provide bioenergy not only from agricultural land, but from our seas and oceans. Seaweed can be used to purify nutrientenriched water (associated with salmon, for example, on farms). Many species of seaweed can be classified in many ways, for instance, by color. Genetic difference between green seaweed Ulva lactuca and brown seaweed Fucus is quite large. U. lactuca has a high sulfur content and usually has a carbon to nitrogen (C: N) ratio of less than 10, which makes anaerobic fermentation difficult. To determine the potential of biogas from different seaweeds of the Gulf of Riga, a study was carried out using laboratory equipment. In the study, 16 different bioreactors fermented at $38{ }^{\circ} \mathrm{C}$ three different types of algae most common in the Gulf of Riga, taken from shorewashed seaweed piles. On average, fermentation for 32 days yielded $0.276 \mathrm{~L} \cdot \mathrm{g}^{-1} \mathrm{dom}$ biogas $\left(0.046 \mathrm{~L} \cdot \mathrm{g}^{-1} \mathrm{dom}\right.$ methane) from brown algae, and $0.248 \mathrm{~L} \cdot \mathrm{g}^{-1} \mathrm{dom}$ biogas $\left(0.027 \mathrm{~L} \cdot \mathrm{g}^{-1} \mathrm{dom}\right.$ methane) from red algae. An average of $0.425 \mathrm{~L} \cdot \mathrm{g}^{-1} \mathrm{dom}$ biogas $\left(0.071 \mathrm{~L} \cdot \mathrm{g}^{-1} \mathrm{dom}\right.$ methane) was obtained from green algae. The study shows that longlived algae can be obtained in small amounts of methane per unit dry organic matter from land-littered ponds, if no measures are taken to condition them.
\end{abstract}

Keywords: biogas, methane, seaweed, anaerobic fermentation, digestate.

\section{Introduction}

The United Nations Intergovernmental Panel on Climate Change (IPCC) report [1], published September 25, 2019in Monte Carlo, indicates that changes will continue and will be irreversible, even if the stabilization of climate is reached. Significantly reducing emissions, thus limiting the loss of glaciers and at the same time focusing on adaptation measures, it is possible to protect the millions of people's livelihoods and to provide a basis for sustainable development, ranging from mountain areas to coastal and sea regions. Since 80 years, the oceans have absorbed $20-30 \%$ of the total anthropogenic emissions. Since 1993, ocean warming rate has more than doubled. Data sets covering the period of 1970-2010, show that the top $(1000 \mathrm{~m})$ ocean surface has lost oxygen levels of 0.5 $3.3 \%$, which in the future will be affected by at least $60 \%$ of all ocean area. The more $\mathrm{CO}_{2}$ oceans absorb, the more acidification of ocean waters takes place. The ocean acidification process and the level of oxygen loss, changing ecosystem structures and their ability to function, have a direct impact on many species, such as corals, mussels and fish. Ocean warming has also led to a reduction in the total catch. In turn, in context of adaptation measures there will be urgent need to adapt not only to the sea level raise, but also higher waves. Wave height will increase significantly in the Southern Ocean, the Pacific Ocean to the east and the Baltic Sea [1] (IPPC report summary 26.09. 2019).

South Baltic area has a strong tourism industry with high recreational value of the negative impact from algae that builds up along the coast. However, the problem can be turned into opportunityby applying biogas production and at the same time preventing eutrophication of coastal waters. The region would have several benefits:

- phosphorus and nitrogen separation from the Baltic Sea and the return to arable land;

- reduction of organic matter leakage from agricultural lands by removing wetlands;

- increasing biodiversity;

- improvement of coastal water availability for juvenile fish and other important organisms.

Justification of bioenergy production from algae is addressed by debate on food versus fuel production in context of Land Use, Land-Use Change and Forestry (LULUCF). Using limited resources of arable land ( 0.2 ha of arable land per capita worldwide) raises ethical questions on energy production in competition with food production. Algae from seas and oceans can produce bioenergy 
instead of using agricultural land for this purpose. Seaweed can purify waters rich in nutrients and can benefit salmon breeding, for instance, at coastal farms.

There may be a number of seaweed species classified for instance by color. The genetic difference between the green seaweed Ulva lactuca and brown seaweed Fucus is quite large.U. lactuca contains a lot of sulfur and has generally the carbon and nitrogen $(\mathrm{C}: \mathrm{N})$ ratio of less than 10 , so the anaerobic fermentation is difficult. There are about 10,000 species of seaweed. Jard et al. (2013) [2] specify seaweeds in three broad parts of the following colors: brown, red and green algae.

- brown algae include Saccharina latissima, Himanthalia elongata, Laminaria digitata, Fucusserratus, Ascophyllum nodosum, Undaria pinnatifida, Sargassum muticum;

- red seaweed include Gracilaria verrucosa, Palmaria palmata and Asparagopsis armata;

- green algae include Codiumtomen tosum and Ulva lactuca.

Biogas yield is dependent on the volatile solids (VS) or total solids (TS) raw material. Bruhnetal (2011) [3] reported about content $57 \%$ of Ulva lactuca VS in Denmark. Allen and al. (2014) [4] found $58 \%$ VS collected from $U$. lactuca content in June 2011 from an estuary in West Cork. Jard et al. (2013) [2] concluded that the summer algae accumulate more carbon and the C: $\mathrm{N}$ ratio would increase and therefore Ulva is with higher VS content.

Using the stoichiometric method Allenetal (2014) [4] showed that the Ulva theoretical maximum methane production could be $431 \mathrm{~L} \cdot \mathrm{kg}^{-1} \mathrm{VS}$ with $51.5 \%$ methane content. Allenetal (2014) [4] reported that algae collected at West Cork in 2013 shown C:N ratio exceeded 20. The optimum anaerobic fermentation $\mathrm{C}: \mathrm{N}$ ratio is from 20 to 1 up to 30 to 1 . Total VS were no more than $8 \%$ up to19\% from naturally wet weight.

Valuesof fresh Ulva of Ireland and Denmark are very similar [5-8]. Bruhn et al. (2011) [3] $U$. lactuca collected from Sedenbeach (Odense fjords), Denmark were the ratio VS/TS was very similar (57\% and $58 \%$ ). Raw, fresh Ulva collected in Ireland show $183 \mathrm{~L} \mathrm{CH}_{4} \cdot \mathrm{kg}^{-1} \mathrm{VS}$, while Ulva in Denmark generated $174 \mathrm{~L} \mathrm{CH}_{4} \cdot \mathrm{kg}^{-1} \mathrm{VS}$ [8]. This suggests that similar results can be obtained from Ulva in the Northern part of Europe.

Biogas potential of red algae Polysiphonia was studied at the Linköping University, Biswas [9] got biogas $0.25-0.27 \mathrm{~m}^{3} \cdot \mathrm{kg}^{-1} \mathrm{VS}$ from untreated algae. Out of autoclave treated algae maximum $0.25 \mathrm{~m}^{3} \cdot \mathrm{kg}^{-1} \mathrm{VS}$ methane was obtained.

Seaweed is appropriate to use in mix with other feedstock. For example, in Denmark Solrod commune a biogas plant together with $53200 \mathrm{t} \cdot \mathrm{y}^{-1}$ of pig slurry $7400 \mathrm{t} \cdot \mathrm{y}^{-1}$ seaweed were used. It is estimated that around $1,141 \mathrm{t} \cdot \mathrm{km}^{-1}$ of coast can be collected. From algae wet weight only $4 \mathrm{~m}^{3} \cdot \mathrm{t}^{-1}$ (from pig manure 10,7 $\mathrm{m}^{3} \cdot \mathrm{t}^{-1}$ ) can be obtained [10] (Solrød Kommune 2014). Seaweeds are also used in Sweden Trelleborg commune biogas plant Smyga. Although, algae collected on the coast had impurity of inorganics (by weight) up to $80 \%$ [11] and for purification of sand special equipment was installed.

Biogas yield from the Gulf of Riga algae in Latvia so far has not been studied.

\section{Materials, techniques and experiment description}

As raw materials three types of algae were collected at the Jaunkemeri beach at the Gulf of Riga: brown, red and green algae. Brown algae Fucusvesiculosus, red algae and green algae Furcellaria Cladophoraglomerata, C. rupestris, Enteromorpha spp. are shown in Figures 1, 2 and 3.

Algae have been taken from the piles on the beach. Samples had very large admixture of sand, as well as strong odor. At first dry matter content was tested. For the red algae dry organic matter was extremely low, just $3.04 \%$. Therefore, additional pretreatment of algae was undertaken and sand with other inorganics was washed off and separated. However, still lot of sand was embedded in the algal pulp and was not fully separated.

For each sample delivered to the laboratory of the University of Life Sciences and Technologiesthe chehemical composition was determined according with ISO 6496: 1999. For each sample and inoculumdry matter, organic solids and ash content were determined. The analysis was made by standard methods [13;14]. Similar methods are also used for energy crops by German researchers (Becker et. al. 2007) [12]. 


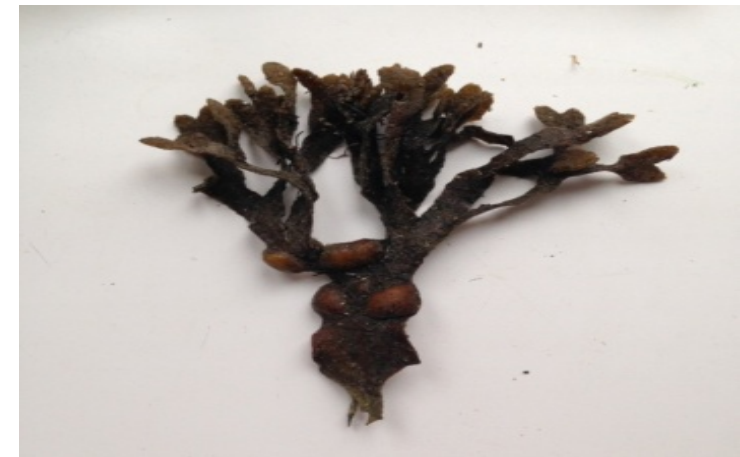

Fig. 1. Brown algae Fucusvesiculosus

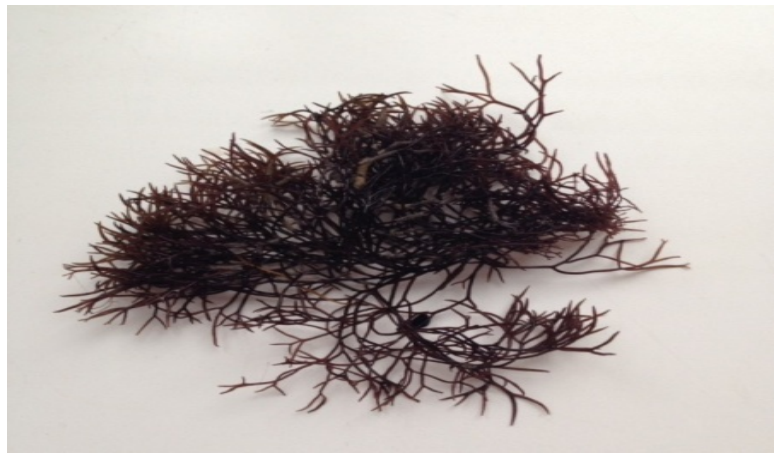

Fig. 2. Red algae Furcellaria

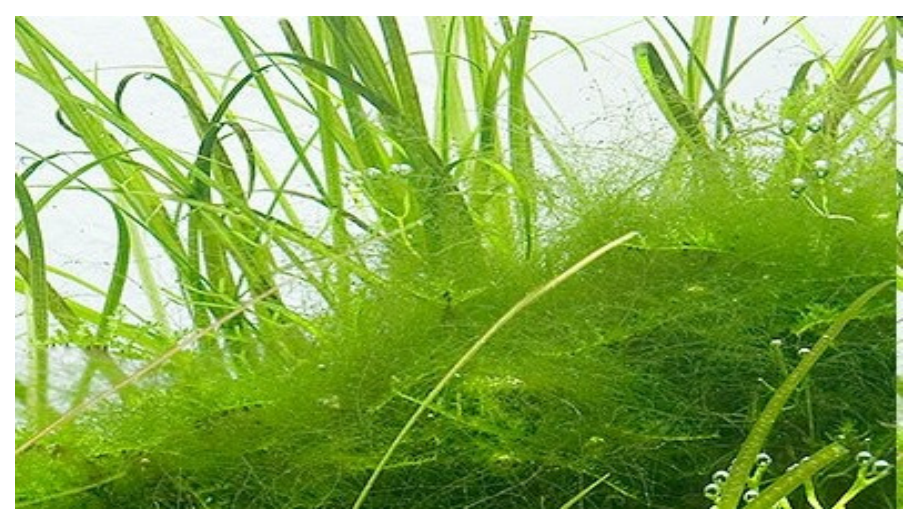

Fig. 3. Green algae Cladophoraglomerata, C. rupestris, Enteromorphaspp

Each group of raw materials was carefully weighed by weighing the sample and inoculum and afterwards thoroughly stirred. For all samples the same inoculum-digestate was used from the continuous operation bioreactor.

All algae prior to the analysis and filling in bioreactors were chopped, cut to $3 \mathrm{~cm}$ pieces. 0.75 liter bioreactors were filled with $20 \mathrm{~g}$ of raw material and $500 \mathrm{~g}$ inoculum (the weight recorded to $0.2 \mathrm{~g}$ accuracy). All data were recorded in the journal of experiments and computer. Bioreactors R2R5 each was charged with a $20 \mathrm{~g}$ of brown seaweeds (BA), R6-R9 by $20 \mathrm{~g}$ of red algae (RA), bioreactors R10-R13 with $20 \mathrm{~g}$ of green algae (GA) and bioreactors R14-R15 each containing $7 \mathrm{~g}$ BA, $7 \mathrm{~g} \mathrm{RA}$ and $7 \mathrm{~g} \mathrm{GA}$. All the bioreactors were connected to the gas storage bags with valves, placed in an oven and installed the operating temperature $38 \pm 0.5^{\circ} \mathrm{C}$. Every day gas volume and composition were measured and recorded. Every day bioreactors were stirred in order to reduce the floating layer. Fermentation took place in a single filling mode and lasted until the biogas seized to generate. Also digestate was weighed and dry matter, ash and organic dry matter content was determined.

Measurement accuracy was $\pm 0: 02 \mathrm{pH}, \pm 0.025 \mathrm{~L}$ gas volume and $\pm 0.1^{\circ} \mathrm{C}$ temperature. Periodically the composition of the produced biogas was determined, including $\mathrm{CH}_{4}$, carbon dioxide $\mathrm{CO}_{2}$, oxygen $\mathrm{O}_{2}$ and hydrogen sulfide $\mathrm{H}_{2} \mathrm{~S}$. Biogas production amount was investigated using laboratory equipment consisting of 160.75 liter bioreactors. Continuous operating temperature was provided by a SNOL type oven. Full dry matter was determined by dry weighing-machine Shimazu at $105^{\circ} \mathrm{C}$ temperature, composition of organic matter with the help of a drying oven Nabertherm and drying process was done with a special program at $550^{\circ} \mathrm{C}$. The gas composition was measured with the gas analyzer GA 2000. The pressure was measured and calculated at the normal volume. The following table provides data calibrated to normal volume. Kern FKB 16KO2scales was used for weight measurement, $\mathrm{pH}$ metering stationary device with accessories (PP-50).

\section{Results and discussion}

Extracted biogas and methane quantities were determined from all 16 digesters. Average values were calculated and presented in tables and visual graphs (Figures). Raw analytical results are shown in Table 1. 
Results of analyzes of raw material samples before anaerobic digestion

\begin{tabular}{|c|c|c|c|c|c|c|c|c|}
\hline $\begin{array}{c}\text { Bio- } \\
\text { reactors }\end{array}$ & Raw material & $\mathbf{p H}$ & $\begin{array}{c}\text { TS } \\
\mathbf{\%}\end{array}$ & $\begin{array}{c}\text { TS } \\
\mathbf{g}\end{array}$ & $\begin{array}{c}\text { ASH, } \\
\mathbf{\%}\end{array}$ & $\begin{array}{c}\text { DOM, } \\
\mathbf{\%}\end{array}$ & $\begin{array}{c}\text { DOM, } \\
\mathbf{g}\end{array}$ & $\begin{array}{c}\text { Weight, } \\
\mathbf{g}\end{array}$ \\
\hline R1; R16 & IN & 7.57 & 4.2 & 21.0 & 19,48 & 80.52 & 16.909 & 500 \\
\hline R2-R5 & BA & - & 36.81 & 7.362 & 48.37 & 51.63 & 3.801 & 20 \\
\hline R2-R5 & IN + BA & - & 5.45 & 28.362 & 26.99 & 73.02 & 20.71 & 520 \\
\hline R 6 R 9 & RA & - & 29.54 & 5.908 & 40,34 & 59.66 & 3,525 & 20 \\
\hline R6-R9 & IN + RA & - & 5.17 & 26.909 & 24.06 & 75.94 & 20.434 & 520 \\
\hline R10-R13 & GA & - & 23.21 & 4.642 & 55.63 & 44.36 & 2,059 & 20 \\
\hline R10-R13 & IN + GA & - & 4.93 & 25.642 & 26.03 & 73.97 & 18.968 & 520 \\
\hline R14-R15 & BA + RA + GA & - & 29.85 & 6.27 & 47.59 & 52.41 & 3.286 & 21 \\
\hline R14-R15 & $\begin{array}{c}\text { IN + BA + RA + G } \\
\text { A }\end{array}$ & - & 5.23 & 27.27 & 35.94 & 74.06 & 20.195 & 521 \\
\hline
\end{tabular}

Note: IN - inoculum; BA - brown algae; RA - red algae; GA - green algae; ASH - ashes;

TS - total solids; DOM or dom - dry organic matter (on raw substrate Basis); R1-R16 bioreactors.

As it is seen from the table, for all algae high dry matter and ash content were observed, but comparing to the traditional raw materials, very low dry organic matter content. This is explained by the large admixture of sand.

Biogas and methane amount extracted from each bioreactor is shown in Table 2. The average yield from starter yeast (inoculum) already deducted.

Table 2

Biogas and methane yields

\begin{tabular}{|c|c|c|c|c|c|}
\hline Bioreactor/Raw material & Biogas, $\mathrm{L}$ & $\begin{array}{l}\text { Biogas, } \\
\mathbf{L}^{-g^{-1} \text { dom }}\end{array}$ & $\begin{array}{l}\text { Methane, } \\
\text { aver. \% }\end{array}$ & Methane, L & $\begin{array}{l}\text { Methane, } \\
\mathrm{L} \cdot \mathrm{g}^{-1} \text { dom }\end{array}$ \\
\hline R1 500g IN & 0.1 & 0.0059 & 3.00 & 0.003 & 0.00018 \\
\hline R16 500g IN & 0.3 & 0.018 & 6.67 & 0.02 & 0.00118 \\
\hline Average R1, R16 & 0.2 & 0.012 & 5.78 & 0.012 & 0.0007 \\
\hline R2 $500 \mathrm{~g} \mathrm{IN}+20 \mathrm{~g}$ BA & 0.9 & 0.237 & 14.56 & 0.131 & 0.034 \\
\hline R3 500g + 20g IN BA & 1.1 & 0.289 & 18.27 & 0.201 & 0.053 \\
\hline R4 500 g IN + 20g BA & 1.1 & 0.289 & 19.64 & 0.216 & 0.057 \\
\hline $\mathrm{R} 5500 \mathrm{~g} \mathrm{IN}+20 \mathrm{~g}$ BA & 1.1 & 0.289 & 12.91 & 0.142 & 0.037 \\
\hline $\begin{array}{l}\text { Average R2- R5 } \\
\pm \text { st.dev. }\end{array}$ & $\begin{array}{ll}1.05 & \\
& \pm 0.10\end{array}$ & \begin{tabular}{|l}
0.276 \\
\pm 0.026
\end{tabular} & $\begin{aligned} 16.48 & \\
& \pm 3.14\end{aligned}$ & $\begin{array}{l}0.173 \\
\pm 0.042\end{array}$ & $\begin{array}{l}0.046 \\
\pm 0.011\end{array}$ \\
\hline R6 $500 \mathrm{~g}+20 \mathrm{~g}$ IN RA & 0.8 & 0.227 & 8.62 & 0.069 & 0.020 \\
\hline R7 $500 \mathrm{~g}+20 \mathrm{~g}$ IN RA & 1.1 & 0.312 & 8.91 & 0.098 & 0.028 \\
\hline R8 $500 \mathrm{~g}+20 \mathrm{~g}$ IN RA & 0.9 & 0.255 & 15.78 & 0.142 & 0.04 \\
\hline R9 $500 \mathrm{~g}+20 \mathrm{~g}$ IN RA & 0.7 & 0.199 & 10.00 & 0.07 & 0.02 \\
\hline $\begin{array}{l}\text { Average: R6-R9 IN + } 20 \\
\text { g RA } \\
\pm \text { st.dev. }\end{array}$ & $\begin{array}{rr}0.875 & \\
& \\
& 0.17 \\
\end{array}$ & $\begin{array}{r}0.248 \\
\pm 0.048 \\
\end{array}$ & $\begin{array}{r}10.86 \\
\\
\pm 3.35\end{array}$ & $\begin{array}{r}0.095 \\
\pm 0.034\end{array}$ & $\begin{array}{r}0.027 \\
\pm 0.009 \\
\end{array}$ \\
\hline R10 $500 \mathrm{~g}+20 \mathrm{~g}$ IN GA & 0.8 & 0.389 & 11.88 & 0.095 & 0.046 \\
\hline R11 $500 \mathrm{~g}+20 \mathrm{~g}$ IN GA & 1.1 & 0.534 & 17.91 & 0.197 & 0.096 \\
\hline R12 $500 \mathrm{~g}+20 \mathrm{~g}$ IN GA & 1.3 & 0.486 & 16.85 & 0.219 & 0.106 \\
\hline R13 $500 \mathrm{~g}+20 \mathrm{~g}$ IN GA & 0.6 & 0.291 & 12.50 & 0.075 & 0.036 \\
\hline $\begin{array}{l}\text { Average R10-R13 } \\
\text { IN + } 20 \text { g GA } \\
\pm \text { st.dev. }\end{array}$ & $0.95 \pm 0.31$ & $\begin{array}{r}0.425 \\
\pm 0.108\end{array}$ & $14.79 \pm 3.04$ & $\begin{array}{r}0.360 \pm 0.39 \\
8\end{array}$ & $\begin{array}{r}0.071 \\
\pm \mathbf{0 . 0 3 5}\end{array}$ \\
\hline $\begin{array}{l}\mathrm{R} 14500 \mathrm{~g} \mathrm{IN}+7 \mathrm{~g} \\
\mathrm{BA}+7 \mathrm{gRA}+7 \mathrm{gGA}\end{array}$ & 0.9 & 0.274 & 16.44 & 0.148 & 0.045 \\
\hline
\end{tabular}


Table 2 (continued)

\begin{tabular}{|c|c|c|c|c|c|}
\hline Bioreactor/Raw material & Biogas, $L$ & $\begin{array}{l}\text { Biogas, } \\
\mathbf{L} \cdot \mathbf{g}^{-1} \text { dom }\end{array}$ & $\begin{array}{c}\text { Methane, } \\
\text { aver. \% }\end{array}$ & Methane, L & $\begin{array}{l}\text { Methane, } \\
{\mathrm{L} \cdot \mathrm{g}^{-1} \text { dom }}\end{array}$ \\
\hline $\begin{array}{l}\mathrm{R} 15500 \mathrm{~g} \mathrm{IN}+7 \mathrm{~g} \\
\mathrm{BA}+7 \mathrm{gRA}+7 \mathrm{gGA}\end{array}$ & 1.0 & 0.304 & 16.40 & 0. & 0.050 \\
\hline $\begin{array}{l}\text { Average R14-R15 500g } \\
\text { IN + 7g } \\
\text { BA + 7gRA + 7gGA } \\
\pm \text { st.dev. }\end{array}$ & $\begin{array}{rrr}0.95 & \\
& \pm 0.07 \\
\end{array}$ & $\begin{array}{r}0.289 \\
\pm 0.021\end{array}$ & $\begin{array}{r}16.42 \\
\pm 0.03\end{array}$ & $\begin{array}{r}0.156 \\
\pm 0.011\end{array}$ & $\begin{array}{r}0.048 \\
\pm 0.004\end{array}$ \\
\hline
\end{tabular}

Note: $L^{\cdot g^{-1}}$ dom - liters per $1 \mathrm{~g}$ of dry organic Matter added (added fresh biomass into inoculums).

Average obtained biogas and methane quantities in comparison to other traditionally used feedstock for biogas production is very small. This is explained by the fact that algae are soaked with sea salts, which inhibit the anaerobic digestion process. This is shown by the very low methane content.

The results obtained in Ireland and Denmark [6-8] are more than three times better. This is explained by the fact that for the purpose of this study no special pretreatment of desalinization of the samples was undertaken to test biogas potential for mechanically collected and untreated feedstock with exemption of mechanical separation of inorganics so far as it is reasonable with simple washing.

The volume of biogas and methane from each bioreactor is shown in Figure 4.

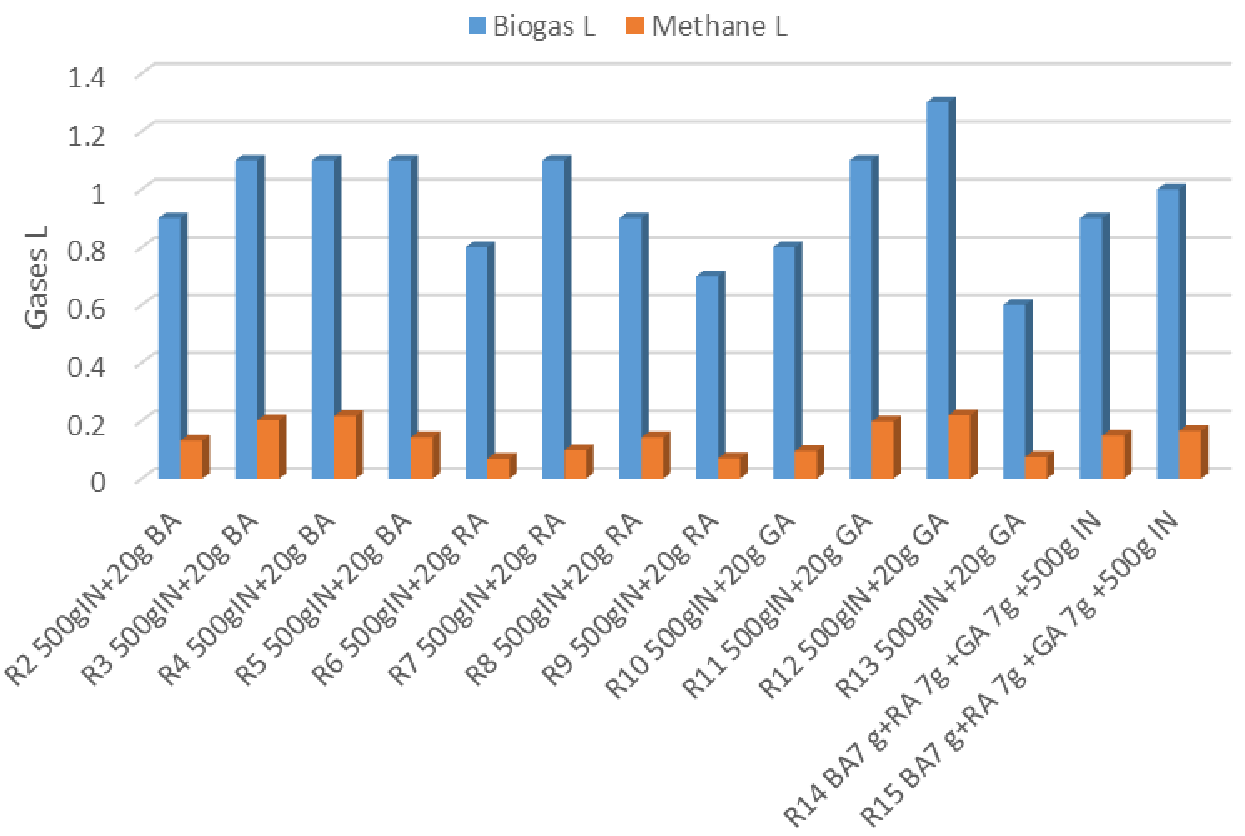

Bioreactors

Fig. 4. Biogas and methane from each bioreactor

The biogas and methane specific outcome is shown in Figure 5. The results show that methane from all algae is representing a very small part of the biogas volume. The biogas composition shows larger amount of $\mathrm{CO}_{2}$ present comparing to methane. This shows that the biomass hydrolysis took place, but methanegenesis was weak.

Thus, within raw materials methane forming bacteria was inhibited by presented of dissolved salts. The concentration of salt in particular samples was not part of this investigation taking into account the tested material close to the status of "as received" for the testing of algae biogas and methane potential with a view to apply anaerobic digestion for algae treatment and bio-energy generation. 


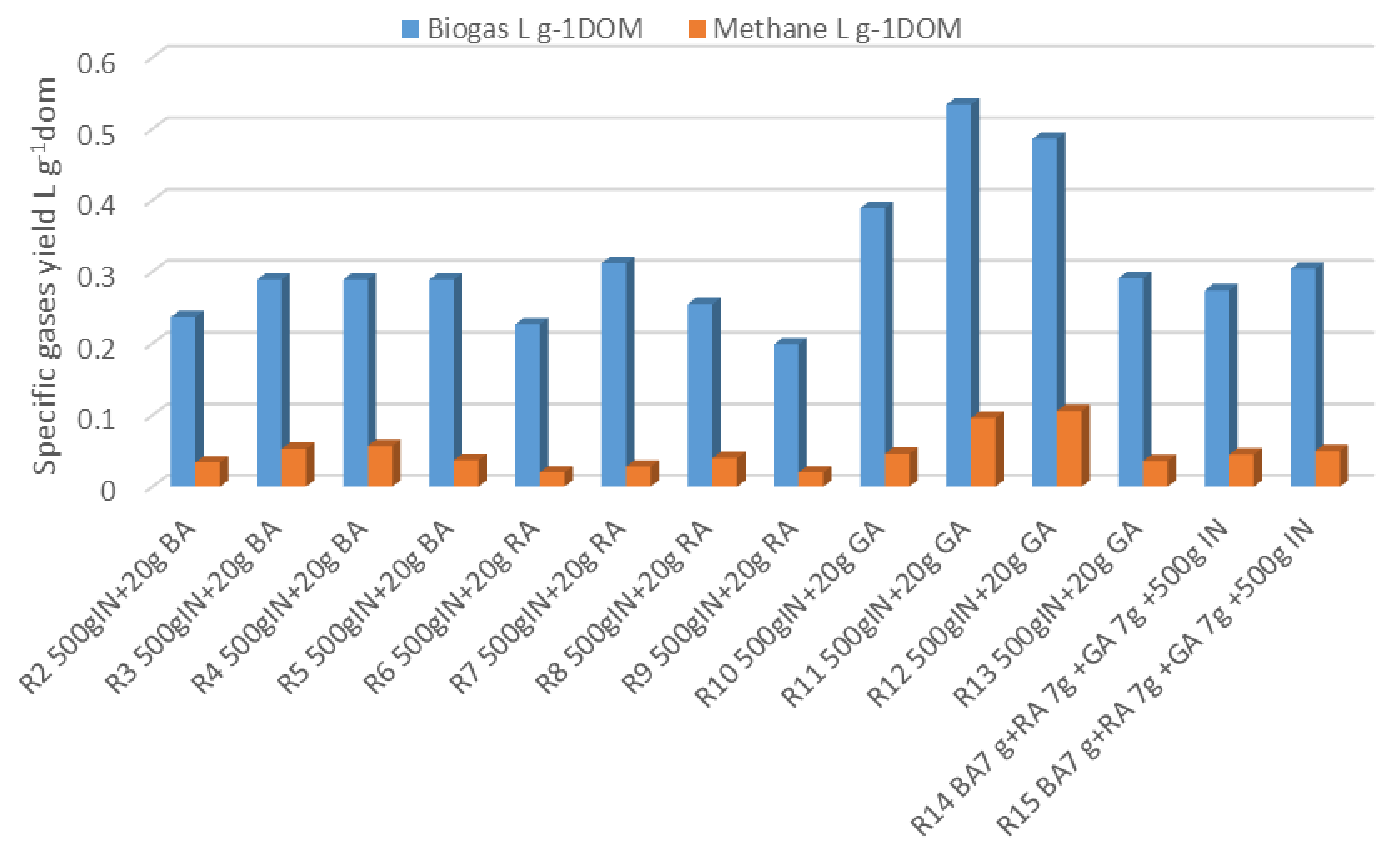

Bioreactors

Fig. 5. Specific biogas and methane yields

\section{Conclusions}

1. Biogas (methane) retrieved from brown algae in average of $0.276 \mathrm{~L} \cdot \mathrm{g}^{-1} \mathrm{dom}\left(0.046 \mathrm{~L} \cdot \mathrm{g}^{-1} \mathrm{dom}\right)$ is a very low yield.

2. Biogas (methane) retrieved from red algae in an average of $0.248 \mathrm{~L} \cdot \mathrm{g}^{-1} \mathrm{dom}\left(0.027 \mathrm{~L} \cdot \mathrm{g}^{-1} \mathrm{dom}\right)$ is a very low yield.

3. Biogas (methane) retrieved from green algae in average of $0,425 \mathrm{~L} \cdot \mathrm{g}^{-1} \mathrm{dom}\left(0.071 \mathrm{~L} \cdot \mathrm{g}^{-1} \mathrm{dom}\right)$ is a slightly better yield, but still a poor result because of low methane content.

4. The overall results show that the algae washed out on the beach is a perspective bio-energy source, but with condition of additional pretreatment to lower the salt concentration. If the feedstock is used "as received" from beach clean-up, the methane yield will be too low to run economically feasible bio-energy generation.

\section{Acknowledgements}

This work has been supported by the project G4 "Feasibility Study of Biomass Anaerobic Fermentation Process Efficiency". LLU program "Conducting fundamental research in LLU”, project G4 (contract No. 3.2.-10/2020 / LLU / 4).

\section{References}

[1] IPCC, Summary for Policymakers. In: IPCC Special Report on the Ocean and Cryosphere in a Changing Climate [H.-O. Portner, DC Robert V. Masson-DELMOTTE, P. Zhai, M. Tignor, E. Poloczanska K. Mintenbeck A. Alegría, Mr Nicolai A. Okemos J. Petzold, B. Rama, NM Weyer (eds.)]. 2019, 36 p.

[2] Jard G., Marfaing H., Carrer H., Delgenes JP., Steyer JP., Dumas C. French Brittany macroalgae screening: Composition and methane Potential Potential for alternative sources of energy and products. Bioresources Technology 144, 2013,pp. 492-498. DOI: 10.1016/j.biortech.2013.06.114.

[3] Bruhn A., Dahl J., Nielsen HB, Nikolaisen L., Rasmussen MB., Markager S., Olesen B., Arias C., Jensen PD. Bioenergy Potential of Ulva lactuca: biomass yield, methane production and combustion. Bioresources Technology 102, 2011, pp. 2595-2604.

[4] Allen E., Wall D., Herrmann C., Xia A., Murphy JD. What is the gross energy yield of third generation gaseous Biofuel sourced from seaweed? Energy 12, 2014. DOI: 10.1016/j.energy.2014.12.048. 
[5] Briand X., Morand P. Anaerobic digestion of Ulva sp. 1. Relationship between about Ulva composition and methanisation. Journal of Applied Phycology 9, 1997, pp. 511-524.

[6] Hughes AD., Black KD., Campbell I., Heyman JJ., Orr KK., Stanley MS., Kelly MS. Comments on "Prospects for the use of macro-algae for fuel in Ireland and UK": An overview of marine management issues. Marine Policy 38, 2013, pp. 554-556.

[7] Vanegas CH., Bartlett J., Green energy from marine algae: biogas production and composition from the anaerobic digestion of Irish seaweed species. Environmental Technology 34 (15), 2013, pp. 2277-2283. DOI: 10.1080/09593330.2013.765922.

[8] Lybæk R . Aquatic biomass for biogas plants - Realistic feedstock source or an academic idea incl. full scale experiences from Solrød biogas plant 2016, 13 p.

[9] Biswas R. Biomethanation of Red Algae from the Baltic Sea Eutrophied MASTER 'STHESIS Linkoping University in 2009, p.65.

[10] Solrod Kommune Solrød Biogas - conception, project development and Realization Written and Published by Solrød Kommune Teknikog Miljø Solrød Center 12680 Solrød Strand 2014.

[11] Tamošiūnas A. Report on anaerobic digestion of cast seaweed Workshop Coastal biogas Malmo 8-9May, 2019, $23 \mathrm{p}$.

[12] Becker C., Dohler H., H. Eckel, et al.Faustzahlen biogas KTBL, FNR 2007, 181p.

[13] Thran D. Methodenhandbuch Energetische Biomassenutzung, (Methods Manual Energetic use of biomass).Leipzig 2010, 93 p. (In German).

[14] VDI 4630 Vergärungorganischer Stoffe substrate charakterisierung, Probenahme, Stoffdatenerhebung, Gärversuche. Vereindeutscher Ingenieure (Fermentation of organic substances Substrate Characterization, sampling, data collection substance, fermentation tests. German Engineers) Düsseldorf, 2006, 48 p. (In German). 